\title{
Implementasi Pembelajaran Berbasis Proyek untuk Meningkatkan Hasil Belajar Siswa pada Mata Pelajaran Matematika di SD Negeri Pinedapa
}

\author{
Manawia H Lapase \\ SD Negeri Pinedapa, Kabupaten Poso - Provinsi Sulawesi Tengah \\ Corresponding Author. Email: Iyalapase6@gmail.com
}

\begin{abstract}
The purpose of this study was to improve mathematics learning outcomes with the subject of calculating the area of a flat shape using a projectbased learning model for grade VI students of SD Negeri Pinedapa. This research uses classroom action research which is carried out in 3 cycles. Each cycle is carried out in 4 (four) stages, namely planning, implementing, observing, and reflecting. The instruments used in this research were tests, observation, and documentation. The data analysis technique used descriptive qualitative and quantitative analysis. The research results from each cycle increased. Based on the results of the cycle III test, it was found that the average learning outcome was 80.31 out of 32 students who scored 70-85 there were 21 students, and the range 86-100 had 11 students. The conclusion of this study is that through the use of a project-based learning model it can improve students' mathematics learning outcomes on the subject of calculating the area of a flat shape in class VI SD Negeri Pinedapa.
\end{abstract}

Abstrak: Tujuan penelitian ini adalah untuk meningkatkan hasil belajar matematika dengan pokok bahasan menghitung luas bangun datar menggunakan model pembelajaran berbasis proyek pada siswa kelas VI SD Negeri Pinedapa. Penelitian ini menggunakan penelitian tindakan kelas yang dilaksanakan dalam 3 siklus. Masing-masing siklus dilaksanakan dalam 4 (empat) tahap, yaitu perencanaan, implementasi, observasi, dan refleksi. Instrumen yang digunakan dalam peneltian ini adalah tes, observasi, dan dokumentasi. Teknik analisis datanya menggunakan analisis deskriptif kualitatif dan kuantitatif. Hasil penelitian dari masing-masing siklus meningkat. Berdasarkan hasil tes siklus III diperoleh rata-rata hasil belajar adalah 80,31 dari 32 siswa yang mendapat nilai 70-85 terdapat 21 siswa, rentang 86-100 terdapat 11 siswa. Kesimpulan dari penelitian ini adalah melalui penggunaan model pembelajaran berbasis proyek dapat meningkatkan hasil belajar matematika siswa pada pokok bahasan menghitung luas bangun datar di kelas VI SD Negeri Pinedapa.

How to Cite: Lapase, M. (2021). Implementasi Pembelajaran Berbasis Proyek untuk Meningkatkan Hasil Belajar Siswa pada Mata Pelajaran Matematika di SD Negeri Pinedapa. Jurnal Paedagogy, 8(2). doi:https://doi.org/10.33394/jp.v8i2.3492

https://doi.org/10.33394/jp.v8i2.3492

This is an open-access article under the CC-BY-SA License.

\author{
Article History \\ Received: 08-02-2021 \\ Revised: 10-03-2021 \\ Published: 04-04-2021
}

\section{Key Words:}

Project-Based

Learning,

Mathematics,

Learning Outcomes.

\section{Sejarah Artikel}

Diterima: 08-02-2021

Direvisi: $10-03-2021$

Diterbitkan: 04-04-2021

\section{Kata Kunci:}

Pembelajaran Berbasis

Proyek, Hasil Belajar,

Matematika.

\section{Pendahuluan}

Pada hakekatnya kegiatan pembelajaran adalah suatu proses interaksi antara guru dan peserta didik dalam satuan pembelajaran. Guru sebagai salah satu komponen dalam proses pembelajaran merupakan pemegang peran yang sangat penting, Guru bukan hanya sekedar penyampai materi saja, tetapi lebih dari itu guru dapat dikatakan sebagai fasilitator, moderator, dan pendidik. Guru sebagai pendidik, agar menarik dalam proses penyampaian materi dituntut adanya Creativity and Innovation yaitu kemampuan seorang guru dalam menciptakan kreativitas yang bisa menghasilkan penemuan-penemuan baru (Handayani, 2020; Mariani, 2020; Heryekti, 2021). Proses pembelajaran ini akan berhasil selain 
ditentukan oleh kemampuan guru dalam menentukan metode dan alat yang digunakan dalam pembelajaran, juga ditentukan oleh minat belajar peserta didik.

Dalam pembelajaran Matematika, banyak guru yang mengeluhkan rendahnya kemampuan siswa dalam menerapkan konsep Matematika. Hal ini terlihat dari banyaknya kesalahan siswa dalam memahami konsep Matematika sehingga mengakibatkan kesalahankesalahan dalam mengerjakan soal (Sulasmi, 2016; Fitrah 2015), sehingga mengakibatkan rendahnya prestasi belajar siswa (skor) baik dalam ulangan harian, ulangan semester, maupun ujian akhir sekolah, padahal dalam pelaksanaan proses pembelajaran di kelas biasanya guru memberikan tugas (pemantapan) secara kontinyu berupa latihan soal. Kondisi riil dalam pelaksanaannya latihan yang diberikan tidak sepenuhnya dapat meningkatkan kemampuan siswa dalam menerapkan konsep Matematika. Rendahnya mutu pembelajaran dapat diartikan kurang efektifnya proses pembelajaran. Penyebabnya dapat berasal dari siswa, guru maupun sarana dan prasarana yang ada, minat dan motivasi siswa yang rendah, kinerja guru yang rendah, serta sarana dan prasarana yang kurang memadai akan menyebabkan pembelajaran menjadi kurang efektif. Saat sekarang ini sistem pembelajaran harus sesuai dengan kurikulum 2013. Jadi pendidikan tidak hanya ditekankan pada aspek kognitif saja tetapi juga afektif dan psikomotorik.

Metode pembelajaran yang kurang efektif dan efisien, menyebabkan tidak seimbangnya kemampuan kognitif, afektif dan psikomotorik, misalnya pembelajaran yang monoton dari waktu ke waktu, guru yang bersifat otoriter dan kurang bersahabat dengan siswa, sehingga siswa merasa bosan dan kurang minat belajar. Untuk mengatasi hal tersebut maka guru sebagai tenaga pengajar dan pendidik harus selalu meningkatkan kualitas profesionalismenya yaitu dengan cara memberikan kesempatan belajar kepada siswa dengan melibatkan siswa secara efektif dalam proses pembelajaran. Juga mengupayakan siswa untuk memiliki hubungan yang erat dengan guru, dengan teman-temannya dan juga dengan lingkungan sekitarnya.

Keberhasilan pembelajaran dalam arti tercapainya standar kompetensi, sangat bergantung pada kemampuan guru mengolah pembelajaran yang dapat menciptakan situasi yang memungkinkan siswa belajar sehingga merupakan titik awal berhasilnya pembelajaran (Semiawan, 2015). Banyaknya teori dan hasil penelitian para ahli pendidikan yang menunjukkan bahwa pembelajaran akan berhasil bila siswa berpartisipasi aktif dalam proses pembelajaran. Salah satu pendekatan pembelajaran yang mengakomodasi implementasi kurikulum 2013 adalah pembelajaran dengan pemberian tugas secara berkelompok.

Pembelajaran Matematika di sekolah juga banyak yang hanya menekankan pada tujuan kognitif. Salah satu alternatif agar pembelajaran Matematika tidak hanya menekankan pada tujuan kognitif saja adalah melalui pembelajaran berbasis proyek. Pembelajaran Matematika berbasis proyek (Project Based Learning (PBL)) bukanlah sekedar pembelajaran yang dipenuhi dengan latihan soal-soal seperti yang sering terjadi di lembaga bimbingan tes (belajar). Dalam pembelajaran berbasis proyek siswa dihadapkan dengan permasalahan yang membangkitkan rasa ingin tahunya untuk melakukan penyelidikan sehingga dapat menemukan sendiri jawabannya, dengan mengkomunikasikan hal itu dengan orang lain.

Dalam penyelidikan sering dilakukan kerjasama dengan temannya. Hal ini memberikan implikasi pada pembelajaran di kelas, termasuk pada pembelajaran Matematika. Pembelajaran Matematika mestinya juga harus menjadi wahana untuk mengembangkan kecakapan dalam memecahkan masalah, karenanya perlu ditetapkan model pembelajaran berbasis proyek sejak dini dan secara berkelanjutan. Matematika merupakan salah satu ilmu 
dasar yang harus dikuasai oleh setiap manusia, terutama oleh peserta didik. Sebab ternyata Matematika tidak dapat dipisahkan dari kehidupan manusia sehari-hari. Salah satu manfaat dalam pembelajaran Matematika adalah untuk mempelajari ilmu-ilmu eksak lainnya akan tetapi hal ini dirasakan sulit oleh para guru untuk menyampaikan pelajaran Matematika agar mudah diterima oleh peserta didik sehingga guru dan peserta didik sama-sama senang dalam proses belajar Matematika.

Rendahnya hasil belajar peserta didik dikarenakan guru dalam menerangkan materi Matematika kurang jelas dan kurang menarik perhatian peserta didik dan pada umumnya guru terlalu cepat dalam menerangkan materi pelajaran. Di samping itu penggunaan metode pengajaran yang salah. Sehingga peserta didik dalam memahami dan menguasai materi masih kurang dan nilai yang diperoleh peserta didik cenderung rendah

Dalam rangka pembaharuan pendidikan, hendaknya guru mampu melibatkan siswanya secara aktif dalam proses belajar sehingga dapat meningkatkan daya kreativitas dan berpikir pada siswa yang dapat memperkuat motivasi. Penerapan kurikulum 2013 merupakan salah satu upaya pemerintah untuk meningkatkan mutu dan kualitas pendidikan agar mampu mencetak generasi penerus yang siap menghadapi masa depan. Kurikulum 2013 dikembangkan dengan menggunakan pendekatan saintifik, yang mengubah pola pikir pembelajaran yang berpusat pada guru menjadi pembelajaran yang berpusat pada siswa. Dengan diterapkannya kurikulum 2013, diharapkan siswa akan lebih aktif dalam mengikuti pembelajaran dan dapat berfikir kreatif untuk menyelesaikan masalah yang dihadapi.

Observasi awal yang dilakukan di kelas VI SD Negeri Pinedapa pada mata pelajaran Matematika, ditemukan berbagai masalah yang menarik perhatian peneliti untuk menyelesaikannya. Salah satu masalah yang ditemukan adalah masih dipakainya metode ceramah dalam pembelajaran. Hal ini mengakibatkan kegiatan belajar mengajar menjadi tidak efektif, karena metode ceramah belum mampu memfasilitasi siswa dalam kegiatan mengamati, menanya, mencoba, mengumpulkan data, mengasosiasi, menalar, dan mengomunikasikan seperti yang tercantum dalam silabus. Masalah lain yang dihadapi adalah kurangnya peralatan dalam melakukan kegiatan percobaan jaringan. Jumlah peralatan yang digunakan dalam percobaan jaringan jumlahnya sangat terbatas jika dibandingkan dengan jumlah siswa yang ada.

Menyikapi masalah tersebut maka dipilih model pembelajaran Project Based Learning (Pembelajaran berbasis proyek) untuk diterapkan pada mata pelajaran Matematika kelas VI SD Negeri Pinedapa. Menurut Sani (2014) model pembelajaran yang sesuai dengan pendekatan saintifik yang dipakai dalam kurikulum 2013, yaitu pembelajaran berbasis Inkuiri, Discovery Learning, dan Pembelajaran berbasis proyek. Alasan dipilihnya model Pembelajaran berbasis proyek dikarenakan Pembelajaran berbasis proyek paling sesuai dengan pelajaran Matematika yang memerlukan banyak kegiatan percobaan. Selain itu SD Negeri Pinedapa sudah menerapkan kurikulum 2013 dalam proses belajar mengajar, jadi penggunaan Pembelajaran berbasis proyek memenuhi syarat untuk dapat diterpakan di SD Negeri Pinedapa. Penggunaan pembelajaran berbasis proyek lebih efektif untuk meningkatkan hasil belajar siswa baik dari aspek kognitif, aspek afektif maupun aspek psikomotorik dibandingkan model pembelajaran konvensional seperti ceramah. Sedangkan menurut Lasonen (dalam Angreadi 2015), pembelajaran berbasis proyek dapat membantu membekali peserta didik untuk memasuki dunia kerja, karena peserta didik belajar bukan hanya secara teori melainkan praktik memecahkan masalah di lapangan. 
Adapun tujuan penelitian ini adalah untuk meningkatkan hasil belajar matematika dengan pokok bahasan menghitung luas bangun datar menggunakan model pembelajaran berbasis proyek pada siswa kelas VI SD Negeri Pinedapa Tahun Pelajaran 2020/2021.

\section{Metode Penelitian}

Pelaksanaan penelitian ini menggunakan metode penelitian tindakan kelas (PTK). Adapun tujuan utama dari PTK adalah untuk memperbaiki/meningkatkan praktek pembelajaran secara berkesinambungan, sedangkan tujuan penyertaannya adalah menumbuhkan budaya meneliti di kalangan guru (Mukhlis, 2010). Penelitian ini menggunakan model penelitian tindakan dari Kemmis dan Taggart (dalam Sugiarti, 2007), yaitu berbentuk spiral dari sklus yang satu ke siklus yang berikutnya. Setiap siklus meliputi planning (rencana), action (tindakan), observation (pengamatan), dan reflection (refleksi). Populasi dalam penelitian ini adalah seluruh siswa kelas VI SD Negeri Pinedapa yang mendapatkan materi pembelajaran Matematika. Pengambilan sampel dilakukan menggunakan teknik Purposive Sampling. Teknik Purposive Sampling adalah teknik pengambilan sampel dengan pertimbangan tertentu. Dalam penelitian ini pertimbangan yang dilakukan adalah dengan mengambil kelas yang mempunyai jumlah siswa sama banyak. Sampel yang dipilih adalah siswa kelas VI SD Negeri Pinedapa. Instrumen yang digunakan dalam peneltian ini adalah tes, observasi, dan dokumentasi. Sedangkan teknik analisis data penelitian ini menggunakan analisis deskriptif kuantitatif dan kualitatif.

\section{Hasil Penelitian dan Pembahasan \\ Deskripsi Siklus I \\ Perencanaan}

Pada tahap perencanaan pembelajaran siklus I, perencanaan dibuat berdasarkan kelemahan-kelemahan yang teridentifikasi pada tahap pra siklus untuk dicari pemecahannya. Adapun tindakan perbaikan yang akan dilakukan melalui Pembelajaran berbasis proyek. Peneliti dengan dibantu oleh teman sejawat membuat rencana pelaksanaan perbaikan pembelajaran.

\section{Implementasi}

Pada kegiatan ini, tindakan yang dilakukan adalah dengan penerapan metode Pembelajaran berbasis proyek yang bertujuan untuk meningkatkan hasil belajar siswa pada pembelajaran Matematika. Kegiatan pembelajaran yang dilakukan merupakan pengembangan dari perencanaan sebelumnya dan dilaksanakan dalam tahap ini. Sebelum memulai pembelajaran guru terlebih dahulu mengatur kelas dan mengabsen siswa selanjutnya memberikan apersepsi kepada siswa tentang materi yang telah dipelajari pada pertemuan sebelumnya. Saat memberikan apersepsi, guru memotivasi siswa agar bersemangat untuk mengikuti proses belajar mengajar. Pada tahap pelaksanaan ini, peneliti melakukan kegiatankegiatan yang sesuai dengan Rencana Pelaksanaan Pembelajaran (RPP) yang dilihat dari kelemahan- kelemahan dari test awal siswa. Dalam tahap pelaksanaan ini, guru mengajar dan menjelaskan materi Menghitung luas bangun datar yang sesuai dengan RPP yang telah dibuat. Dalam proses belajar mengajar pertama guru menjelaskan tentang pengumpulan dan pengolahan data, kemudian dilanjutkan dengan pemberian tugas melalui kartu masalah untuk didiskusikan secara berkelompok, dilakukan pembahasan dan penarikan kesimpulan secara bersama-sama. Pada Siklus I siswa yang tuntas atau telah mencapai KKM dalam belajarnya sebanyak 20 siswa atau $62,5 \%$ dari 32 siswa, dan siswa yang belum tuntas atau belum mencapai KKM sebanyak 12 siswa atau 37,5\%. 


\section{Observasi}

Pada tahap ini peneliti dan guru kelas VI melakukan observasi dengan menggunakan daftar chek list terhadap pelaksanaan kegiatan pembelajaran yang telah dilakukan peneliti. Setelah pelaksanaan siklus I selesai diberikan pos test I untuk melihat keberhasilan tindakan yang dilakukan dan untuk melihat kesulitan yang masih dialami oleh siswa. Data observasi menunjukan rata-rata aktivitas siswa pada siklus I pertemuan I kurang aktif dalam proses pembelajaran. Hal itu ditunjukan dengan rata-rata prosentase aktivitas belajar siswa pada proses pembelajaran siklus I pertemuan I mencapai 66,11. Pada siklus I ini belum nampak keaktifan siswa untuk bertanya dan memberikan pendapatnya terhadap materi yang diajarkan. Hal itu ditunjukan dari 32 siswa hanya 14 siswa atau sebesar 43,75\%, siswa yang aktif bertanya 11 siswa atau sebesar $34,38 \%$ siswa yang memberikan pendapatnya ketika diberi kesempatan.

Aktivitas guru pada siklus I pertemuan I kurang aktif dalam proses pembelajaran. Hal itu ditunjukan dengan rata-rata prosentase aktivitas mengajar guru pada proses pembelajaran siklus I pertemuan I mencapai 72,20. Pada siklus I ini belum nampak keaktifan guru untuk memotivasi siswa untuk belajar. Hal itu ditunjukan kemampuan guru untuk menggunakan metode Pembelajaran berbasis proyek sebesar 9,38\%, Guru dalam membimbing siswa mengarahkan kejawaban yang benar sebesar 6,25\%. Jadi, tindakan perbaikan siklus I dengan menggunakan model Pembelajaran berbasis proyek ini sudah terdapat peningkatan hasil belajar siswa jika dibandingkan dengan hasil tes formatif pada tahap pra siklus walaupun belum mencapai tingkat ketuntasan maksimal.

\section{Refleksi}

Berdasarkan hasil tes pada siklus I, nilai rata-rata hasil belajar yang dicapai siswa adalah 76,28 masih jauh di bawah indikator keberhasilan yang ditetapkan. Hal ini terjadi karena disebabkan beberapa faktor diantaranya guru masih belum terbiasa melakukan pembelajaran berbasis proyek dan pada saat pembelajaran hanya sebagian kecil siswa yang dapat menjawab pertanyaan guru dan dapat menanggapi serta memberi contoh atas penjelasan dari guru. Hal ini dikarenakan siswa belum terbiasa melakukan pembelajaran berbasis proyek. Uraian ini menyatakan bahwa pada siklus I indikator keberhasilan belum tercapai. Oleh karena itu, perlu adanya suatu tindakan pada siklus II agar hasil belajar siswa dapat ditingkatkan dan mencapai indikator keberhasilan yang ditetapkan.

\section{Deskripsi Siklus II \\ Perencanaan}

Pada tahap perencanaan pembelajaran siklus II, perencanaan dibuat berdasarkan kelemahan-kelemahan yang teridentifikasi pada siklus I untuk dicari pemecahannya. Adapun tindakan perbaikan yang akan dilakukan melalui Pembelajaran berbasis proyek. Peneliti dengan dibantu oleh teman sejawat membuat rencana pelaksanaan perbaikan pembelajaran.

\section{Implementasi}

Pada kegiatan ini, tindakan yang dilakukan adalah dengan penerapan metode Pembelajaran berbasis proyek yang bertujuan untuk meningkatkan hasil belajar siswa pada pembelajaran Matematika. Kegiatan pembelajaran yang dilakukan merupakan pengembangan dari perencanaan sebelumnya dan dilaksanakan dalam tahap ini. Sebelum memulai pembelajaran guru terlebih dahulu mengatur kelas dan mengabsen siswa selanjutnya memberikan apersepsi kepada siswa tentang materi yang telah dipelajari pada pertemuan sebelumnya. Saat memberikan apersepsi, guru memotivasi siswa agar bersemangat untuk mengikuti proses belajar mengajar. Pada tahap pelaksanaan ini, peneliti melakukan kegiatan- 
kegiatan yang sesuai dengan Rencana Pelaksanaan Pembelajaran (RPP) yang dilihat dari kelemahan-kelemahan dari test awal siswa. Dalam tahap pelaksanaan ini, guru mengajar dan menjelaskan materi Menghitung luas bangun datar yang sesuai dengan RPP yang telah dibuat. Dalam proses belajar mengajar pertama guru menjelaskan tentang pengumpulan dan pengolahan data, kemudian dilanjutkan dengan pemberian tugas melalui kartu masalah untuk didiskusikan secara berkelompok, dilakukan pembahasan dan penarikan kesimpulan secara bersama-sama. Pada Siklus II siswa yang tuntas atau telah mencapai KKM dalam belajarnya sebanyak 27 siswa atau 84,38\% dari 32 siswa, dan siswa yang belum tuntas atau belum mencapai KKM sebanyak 5 siswa atau 15,63\%.

\section{Observasi}

Pada tahap ini peneliti dan guru kelas VI melakukan observasi dengan menggunakan daftar chek list terhadap pelaksanaan kegiatan pembelajaran yang telah dilakukan peneliti. Setelah pelaksanaan siklus I selesai diberikan pos test II untuk melihat keberhasilan tindakan yang dilakukan dan untuk melihat kesulitan yang masih dialami oleh siswa. Pada akhir pertemuan siklus II setelah semua materi diajarkan, maka siswa diberikan test hasil belajar untuk mengetahui sejauh mana perkembangan hasil belajar siswa.

Rata-rata aktivitas siswa pada siklus II pertemuan I kurang aktif dalam proses pembelajaran. Hal itu ditunjukan dengan rata-rata prosentase aktivitas belajar siswa pada proses pembelajaran siklus II pertemuan I mencapai 75,72. Pada siklus II ini belum nampak keaktifan siswa untuk bertanya dan memberikan pendapatnya terhadap materi yang diajarkan. Hal itu ditunjukan dari 32 siswa hanya 18 siswa atau sebesar 56,25\%, siswa yang aktif bertanya 14 siswa atau sebesar $43,75 \%$ siswa yang memberikan pendapatnya ketika diberi kesempatan. Rata-rata aktivitas guru pada siklus II pertemuan I kurang aktif dalam proses pembelajaran. Hal itu ditunjukan dengan rata-rata prosentase aktivitas mengajar guru pada proses pembelajaran siklus II pertemuan I mencapai 80,60. Pada siklus II ini sudah nampak keaktifan guru untuk memotivasi siswa untuk belajar. Jadi, tindakan perbaikan siklus II dengan menggunakan model Pembelajaran berbasis proyek ini sudah terdapat peningkatan hasil belajar siswa jika dibandingkan dengan hasil tes formatif pada tahap pra siklus walaupun belum mencapai tingkat ketuntasan maksimal.

\section{Refleksi}

Berdasarkan hasil tes pada siklus II, nilai rata-rata hasil belajar yang dicapai siswa adalah 80,64 masih jauh di bawah indikator keberhasilan yang ditetapkan. Hal ini terjadi karena disebabkan beberapa faktor diantaranya guru masih belum terbiasa melakukan pembelajaran berbasis proyek dan dalam kerja kelompok yang penentunya tempat duduk, hanya sebagian siswa yang mengambil bagian dalam diskusi atau masih ada siswa yang tidak ikut serta dalam kerja kelompok. Pada saat satu kelompok menyajikan hasil karya kelompoknya banyak siswa yang tidak memperhatikan, mereka cenderung bermain dan berbicara sendiri. Uraian ini menyatakan bahwa pada siklus II indikator keberhasilan belum tercapai. Oleh karena itu perlu adanya suatu tindakan pada siklus III agar hasil belajar siswa dapat ditingkatkan dan mencapai indikator keberhasilan yang ditetapkan.

\section{Deskripsi Siklus III \\ Perencanaan}

Dari hasil refleksi pada siklus II dapat disimpulkan bahwa kegiatan pembelajaran belum begitu baik dan siswa masih ada yang belum aktif dalam belajar, sehingga hasil yang diperoleh siswa belum mencapai tingkat ketuntasan. Kegiatan yang dilakukan dalam siklus III sama dengan siklus II adalah perencanaan ini mempersiapkan rencana pelaksanaan 
pembelajaran RPP sub Menghitung luas bangun datar hanya saja dalam pelaksanaan perbaikan pembelajaran siklus III ini guru lebih mengorganisasi waktu dengan baik, memotivasi siswa untuk aktif dalam memberikan tanggapan atau memberi contoh, dan membuat alat pengumpulan data berupa lembar observasi untuk guru dan siswa guna mengamati proses pembelajaran dan test dilakukan pada setiap pertemuan untuk mengetahui tingkat keberhasilan siswa dalam tiap siklus.

\section{Implementasi}

Dalam kegiatan ini, guru melaksanakan kegiatan belajar dan mengajar berdasarkan Rencana Pelaksanaan Pembelajaran (RPP) dengan menggunakan Pembelajaran berbasis proyek yang bertujuan untuk meningkatkan hasil belajar siswa pada sub pokok Menghitung luas bangun datar. Pada tahap ini kegiatan yang dilakukan sama dengan siklus I, hal ini dikarenakan berdasarkan hasil observasi yang dilakukan, banyak siswa yang termotivasi untuk mencari dan menemukan jawaban dari masalah-masalah yang dikemukakan dari materi Menghitung luas bangun datar dengan cara kerja kelompok. Dalam tahap pelaksanaan ini, guru mengajar dan menjelaskan materi Menghitung luas bangun datar yang sesuai dengan RPP yang telah dibuat. Dalam proses belajar mengajar pertama guru menjelaskan tentang materi Menghitung luas bangun datar, setelah itu guru mengemukakan masalah atau kasus guna mengajak siswa untuk menjawab pertanyaan dari masalah yang terdapat pada materi Menghitung luas bangun datar. Setelah mengemukakan masalah atau kasus, guru meminta siswa untuk membentuk kelompok belajar guru memecahkan masalah atau kasus yang telah dikemukakan. Pada proses pembelajaran ini guru berkeliling untuk mengawasi siswa pada tiap- tiap kelompok. Setelah menyelesaikan masing-masing latihan yang diberikan. Setelah siswa selesai berdiskusi guru meminta hasil laporan kelompok yang telah disusun siswa dan guru meminta masing-masing perwakilan dari kelompok untuk mempersentasekan hasil kerja kelompoknya. Guru menanggapi hasil kerja siswa dan menyimpulkan materi tentang Menghitung luas bangun datar.

Table 1. Distribusi Frekuensi dan Prosentase dari Nilai Presentasi dan Tes Hasil Belajar Siswa Pada Siklus III

\begin{tabular}{|c|c|c|c|}
\hline Nilai & Frekuensi & Prosentase (\%) & Keterangan \\
\hline $86-100$ & 11 & 34,38 & Tuntas \\
\hline $70-85$ & 21 & 65,62 & Tuntas \\
\hline Jumlah & 32 & 100 & \\
\hline
\end{tabular}

Berdasar tabel diatas dapat diketahui bahwa semua siswa sudah tuntas belajar atau sama dengan KKM $\geq 70$. Distribusi frekuensi nilai presentasi dan tes hasil belajar siswa pada siklus II yaitu dari 32 siswa yang mendapat nilai 70 - 85 terdapat 21 siswa, rentang 86 - 100 terdapat 11 siswa. Berikut ini disajikan distribusi ketuntasan nilai presentasi dan tes hasil belajar siswa pada siklus II pada materi pokok Menghitung luas bangun datar.

Tabel 2. Deskripsi Ketuntasan Nilai Presentasi dan Tes Hasil Belajar Siswa Siklus III

\begin{tabular}{|c|c|c|c|}
\hline $\begin{array}{c}\text { N (Jumlah } \\
\text { siswa) }\end{array}$ & $\begin{array}{c}\text { Siswa yang } \\
\text { belum tuntas }\end{array}$ & $\begin{array}{c}\text { Siswa yang } \\
\text { sudah tuntas }\end{array}$ & $\begin{array}{c}\text { Mean } \\
\text { (Rata-rata) }\end{array}$ \\
\hline 32 & 0 & 32 & 86,25 \\
\hline
\end{tabular}


Berdasarkan tabel diatas dapat diketahui bahwa semua siswa sudah mencapai ketuntasan belajar pada siklus III. Rata-rata nilai pada siklus III diketahui sebanyak 86,13 . Analisis data dari observasi siswa, dapat diketahui bahwa keaktifan siswa dari semua aspek pada pertemuan 1 sampai dengan pertemuan 2 sudah dilakukan sebagian besar siswa sekitar 85\% dari jumlah siswa. Berdasarkan lembar observasi guru dibandingkan pada siklus I dan siklus II dan pembelajaran sudah berjalan sesuai harapan.

\section{Observasi}

Pada tahap ini peneliti dan guru kelas VI melakukan observasi dengan menggunakan daftar chek list terhadap pelaksanaan kegiatan pembelajaran yang telah dilakukan peneliti. Setelah pelaksanaan siklus III selesai diberikan pos test III untuk melihat keberhasilan tindakan yang dilakukan dan untuk melihat kesulitan yang masih dialami oleh siswa. Ratarata aktivitas guru pada siklus I pertemuan I kurang aktif dalam proses pembelajaran. Hal itu ditunjukan dengan rata-rata prosentase aktivitas mengajar guru pada proses pembelajaran siklus II pertemuan I mencapai 93,80\%. Pada siklus III ini sudah nampak keaktifan guru untuk memotivasi siswa untuk belajar. Hal itu ditunjukan kemampuan guru untuk menggunakan metode sebesar 9,38\%, Guru dalam membimbing siswa mengarahkan kejawaban yang benarsebesar $9,38 \%$.

\section{Refleksi}

Berdasarkan hasil tes siswa pada siklus III, nilai rata-rata hasil belajar yang dicapai siswa adalah 80,31. Hal ini dipengaruhi oleh beberapa faktor diantaranya yakni pembelajaran berbasis proyek yang dilakukan oleh guru pada siklus III berlangsung efektif. Guru sudah berhasil mengorgaisasikan waktu dengan baik. Dalam pembelajaran guru sudah dapat memotivasi siswa untuk aktif seperti siswa dapat memberikan tanggapan/memberi contoh atas penjelasan dari guru, siswa dapat menjawab pertanyaan guru dengan benar. Secara umum, dalam siklus II ini guru sudah berhasil melaksanakan Pembelajaran berbasis proyek. Dalam siklus III ini, seluruh siswa hadir dalam pembelajaran. Siswa sangat aktif dalam pembelajaran. Sebagian besar siswa mampu menjawab pertanyaan guru dengan benar, siswa berani menyampaikan pendapat dan menanggapi siswa lain. Dalam kerja kelompok hampir seluruh siswa berpartisipasi aktif/ambil bagian di dalamnya. Pada saat satu kelompok mempresentasikan hasil karya kelompoknya, siswa yang lain memperhatikan dengan baik.

\section{Pembahasan}

Pembahasan yang dilakukan didasarkan atas hasil observasi yang dilanjutkan dengan refleksi pada setiap siklus tindakan. Pembelajaran pada mata pelajaran Matematika tentang Menghitung luas bangun datar yang dilakukan selama penelitian berlangsung terdapat peningkatan-peningkatan ke arah perbaikan. Pada siklus I pembelajaran Matematika yang dilaksanakan guru sudah cukup baik, namun ada ada beberapa hal yang perlu diperbaiki, diantaranya bimbingan yang diberikan oleh guru kurang merata, sehingga banyak kelompok yang tidak dapat menyelesaikan permasalahan yang diberikan. Dari 4 (empat) kelompok hanya 1 (satu) kelompok yang dapat menyelesaikan permasalahan yang diberikan dengan baik. Hal ini dipengaruhi oleh beberapa faktor, antara lain kemampuan siswa itu sendiri yang memang kurang baik/tidak begitu pandai dan bimbingan guru yang kurang. Bimbingan individu juga masih kurang, sehingga hanya sebagian siswa yang aktif dalam diskusi kelompok. Guru tidak memberikan bimbingan kepada siswa pada saat menuliskan hasil diskusi pemecahan masalah pada lembar presentasi. Tulisan mereka terlalu kecil sehingga tidak terbaca oleh siswa yang duduk di belakang. Selain itu suara mereka juga kurang keras sehingga hanya didengar oleh siswa yang duduk di depan. 
Sedangkan siswa yang lain tidak memperhatikan. Dengan kata lain siswa tidak dapat sepenuhnya mengamati presentasi hasil kelompok. Pada akhir pelajaran penarikan simpulan dilakukan oleh guru, seharusnya siswalah yang mengambil kesimpulan.

Pengelolaan waktu pada siklus I dan siklus II belum begitu baik. Waktu untuk mengerjakan kartu masalah terlalu lama sehingga pada saat presentasi hanya 1 (satu) kelompok yang dapat mempresentasikan hasil diskusi kelompoknya karena waktunya yang tidak memungkinkan. Aktivitas belajar siswa sudah baik, namun jumlah siswa yang mampu memberikan tanggapan/memberi contoh atas penjelasan guru dan yang mampu menjawab pertanyaan masih sedikit. Dalam diskusi kelompok hanya didominasi oleh siswa yang pandai. Dengan demikian perlu adanya upaya untuk meningkatkan aktivitas siswa diantaranya dengan dalam pembelajaran guru selalu memberikan motivasi pada siswa. Berdasarkan hasil angket refleksi siswa pada siklus I, pembelajaran Matematika yang dilaksanakan menyenangkan dan mudah diikuti. Namun ada sebagian siswa yang merasa pembelajaran tersebut membuat mereka bingung. Siswa merasa senang bekerja kelompok. Penyajian hasil karya (saat presentasi) yang dilaksanakan menyenangkan bagi mereka. Soal pemecahan masalah yang diajukan menarik dan mendorong mereka untuk terus belajar Matematika.

Pada siklus II, pelaksanaan pembelajaran Matematika sudah baik. Proses pembelajaran yang dilaksanakan guru pada siklus II sudah mencerminkan ciri dari Pembelajaran berbasis proyek, seperti yang dikemukakan oleh Ismail (2002) bahwa ciri utama Pembelajaran berbasis proyek adalah pengajuan pertanyaan, memusatkan kepada keterkaitan antar disiplin, penyelidikan autentik, kerjasama dan menghasilkan hasil karya atau peragaan. Guru sudah menjelaskan tujuan pembelajaran dengan lengkap, sudah memunculkan masalah dengan baik dan sudah memberikan motivasi dengan baik kepada siswa. Bimbingan yang diberikan guru dalam proses penyelesaian masalah sudah baik dan lebih merata dari siklus sebelumnya. Guru sudah berkeliling pada saat diskusi kelompok dan membantu siswa yang mengalami kesulitan. Bimbingan yang diberikan guru juga sudah meningkat, meskipun masih ada siswa yang tidak aktif dalam pembelajaran namun jumlahnya relatif sedikit. Guru juga sudah memberikan bimbingan kepada siswa pada saat presentasi. Tulisan sudah besar dan suaranya juga sudah keras, sehingga bisa didengar oleh semua siswa. Guru memberikan kesempatan kepada siswa untuk memberikan tanggapan atas presentasi yang dilaksanakan. Penarikan simpulan dilakukan oleh siswa dengan bimbingan guru. Pada siklus II siswa sudah mempunyai pengalaman dalam mengikuti Pembelajaran berbasis proyek. Mereka mulai terbiasa bekerja kelompok. Pembentukan kelompok yang dilakukan dengan memperhatikan penyebaran kemampuan siswa, ada yang pandai dan ada yang kurang pandai memungkinkan mereka untuk bekerjasama dan berbagi pendapat dalam diskusi kelompok. Siswa yang pandai dengan sabar memberikan bimbingan kepada siswa yang kurang pandai sehingga diskusi kelompok dapat berlangsung dengan baik. Kemampuan siswa dalam menyelesaikan masalah terlihat lebih baik. Dari 4 (empat) kelompok, 3 (tiga) kelompok sudah dapat menyelesaikan permasalahan dengan baik. Berdasarkan hasil tes siklus III diperoleh rata-rata hasil belajar adalah 86,13 dari 32 siswa yang mendapat nilai 70 85 terdapat 25 siswa, rentang 86-100 terdapat 7 siswa. Dalam mengatasi masalah siswa yang belum tuntas dengan cara guru memberikan waktu khusus kepada siswa untuk memberi bimbingan dan motivasi supaya siswa tersebut mau belajar kelompok dengan teman terdekat. Dengan demikian pembelajaran berbasis proyek dapat meningkatkan hasil belajar Matematika pokok bahasan Menghitung luas bangun datar siswa kelas VI SD Negeri Pinedapa Tahun Pelajaran 2020/2021. 


\section{Kesimpulan}

Berdasarkan penelitian yang telah dilaksanakan dapat disimpulkan bahwa hasil penelitian dari masing-masing siklus meningkat. Hal ini dibuktikan dengan data hasil tes siklus III diperoleh rata-rata hasil belajar adalah 80,31 dari 32 siswa yang mendapat nilai 7085 terdapat 21 siswa, rentang 86-100 terdapat 11 siswa. Sehingga melalui penggunaan model pembelajaran berbasis proyek dapat meningkatkan hasil belajar matematika siswa pada pokok bahasan menghitung luas bangun datar di kelas VI SD Negeri Pinedapa.

\section{Saran}

Adapun saran yang dapat disampaikan berdasarkan hasil penelitian ini antara lain adalah (1) Siswa hendaknya berlatih mempraktikkan proyek dengan menggunakan metode berbasis proyek sehingga siswa bisa materi yang dipelajari dapat dipraktekkan dalam kehidupan sehari-hari; (2) Bagi Guru agar model pembelajaran berbasis proyek dapat digunakan untuk mata pelajaran lain. (3) Bagi Kepala Sekolah menyarankan kepada guruguru lain agar menerapkan Pembelajaran berbasis proyek dalam upaya meningkatkan hasil belajar siswa, karena dengan metode Pembelajaran berbasis proyek menolong siswa untuk dapat mengembangkan ketrampilan berfikir dengan memberikan pertanyaanpertanyaan dan mendapatkan jawaban atas dasar rasa ingin tahu mereka.

\section{Daftar Pustaka}

Arifin, Z. (2012). Evaluasi Pembelajaran. Jakarta : Direktorat Jenderal Pendidikan Islam

Kementerian Agama RI.

Djamarah, S. (2010). Strategi Belajar Mengajar.Jakarta: Rineka Cipta.

Fitrah, M. (2015). Mengidentifikasi Faktor Penghambat Guru Matematika Kecamatan Dompu NTB Terhadap Proses Pembelajaran pada Sekolah Menengah Atas. Jurnal Kependidikan: Jurnal Hasil Penelitian dan Kajian Kepustakaan di Bidang Pendidikan, Pengajaran dan Pembelajaran, $1(1)$. doi:https://doi.org/10.33394/jk.v1i1.401

Hariyanto dan Suyono. (2011). Belajar dan Pembelajaran. Bandung : Remaja Rosdakarya. Handayani, L. (2020). Peningkatan Motivasi Belajar IPA Melalui Model Pembelajaran Project Based Learning pada Masa Pandemi Covid-19 bagi Siswa SMP Negeri 4 Gunungsari. Jurnal Paedagogy, $\quad 7(3), \quad$ 168-174. doi:https://doi.org/10.33394/jp.v7i3.2726

Heryekti Pujingsih, R. (2021). Meningkatkan Motivasi dan Hasil Belajar Matematika dengan Metode Kooperatif Tipe Jigsaw di SMA Negeri 1 Gerung. Jurnal Paedagogy, 8(1), 50-56. doi:https://doi.org/10.33394/jp.v8i1.3196

Mariani Artini, N. (2020). PEMBELAJARAN MODEL STAD UNTUK MENINGKATKAN PRESTASI BELAJAR MATEMATIKA PADA SISWA KELAS V SDN 39 CAKRANEGARA. Jurnal Paedagogy, 30-37. doi:https://doi.org/10.33394/jp.v3i1.3033

Muslich, M. (2011). Penilaian Berbasis Kelas dan Kompetensi. Bandung : Refika Aditama.

Sani, R, A. (2014). Pembelajaran Saintifik untuk Implementasi Kurikulum 2013. Jakarta : Bumi Aksara

Sulasmi, S. (2016). Meningkatkan Prestasi Belajar Matematika dengan Pendekatan CTL. Jurnal Kependidikan: Jurnal Hasil Penelitian dan Kajian Kepustakaan di Bidang Pendidikan, Pengajaran dan Pembelajaran, 2(1). doi:https://doi.org/10.33394/jk.v2i1.450 